\title{
PATIENTS' SATISFACTION WITH DENTAL CARE (ON THE RESULTS OF SOCIOLOGICAL RESEARCH)
}

DOI: $10.36740 /$ WLek202103220

\author{
Anatoly G. Krut, Viktoriia V. Horachuk \\ SHUPYK NATIONAL MEDICAL ACADEMY OF POSTGRADUATE EDUCATION, KYIV, UKRAINE
}

\begin{abstract}
The aim: To determine the level of patients' satisfaction with the received dental care in regional dental clinic and to make proposals for improving the quality of dental care based on the survey results.

Materials and methods: 221 copies of the questionnaires completed by the respondents; sociological method (questionnaire), medical-statistical, analysis and bibliosemantic methods were used.

Results: Patients expressed high satisfaction with the quality of dental care according to the criteria of geographical accessibility ( $4.28 \pm 0.05$ points), the conditions in the doctor's office ( $4.63 \pm 0.04$ points), safety of dental interventions ( $4.54 \pm 0.04$ points) and their effectiveness ( $4.58 \pm 0.04$ points), the attitude of the doctor to the patient ( $4.75 \pm$ 0.03 points), the clarity of information for the patient ( $4.52 \pm 0.04$ points). However, the satisfaction of patients with the cost of dental services was only $3.76 \pm 0.05$ points. Conclusions: Patients' satisfaction with the financial accessibility of dental care was found to be lower compared to satisfaction with other healthcare quality components. This information can be used to make management decisions on revising the coverage of the cost of dental services from the state budget and other sources of funding.
\end{abstract}

KEY WORDS: healthcare quality; patients' satisfaction; financial accessibility of dental care

Wiad Lek. 2021;74(3 p.II):674-677

\section{INTRODUCTION}

WHO's conceptual approaches to intensification the delivery of health services to people require a strengthening of health systems. Close interaction of patients with healthcare tools and processes should be an essential component of these systems [1]. Patients make an important contribution to the evaluation of the quality of care. This can help health care managers identify opportunities to improve health care, increase public confidence in the health care setting, and analyze the causes of differences between patients' expectations and their level of satisfaction with health care $[2,3]$.

A number of health care quality regulation tools have been introduced in Ukraine since the end of the last century: licensing of medical practices, accreditation and certification of healthcare institutions, standardization of medical technologies. Thus, 95 healthcare institutions, including 26 state-owned, 30 communal and 39 private-owned, received the highest accreditation category and certified their quality management systems in 2017. Certification was carried out in accordance with the requirements of national standards for quality management systems, authentic ISO 9001 series standards [4].

There are eight powerful independent institutions of dental profile, among those institutions that have received certificates: regional dental clinics in Kharkiv, Dnipro, Odessa, Chernihiv, Khmelnitsky, dental polyclinic of the Ministry of Health of Ukraine, located in Chernomorsk (Odessa region), Dental practical training medical center of Shupyk National Medical Academy of Postgraduate Education (Kyiv), French Dental Center (Kyiv).

The requirements of the standard include, in particular, the assessment of patients' satisfaction with dental care in the above institutions. Satisfaction data can be used to design interventions to improve the quality of dental care.

\section{THE AIM}

To determine the level of patients' satisfaction with the received dental care and to make proposals for improving the quality of dental care based on the survey results. To achieve the goal of the study, the task was to conduct a sociological survey among patients of the regional dental clinic in Chernihiv and to analyze the results.

\section{MATERIALS AND METHODS}

Methods of sociological (questionnaire), medical-statistical, bibliosemantic and analysis were used in the study. National Standard «DSTU ISO 10004: 2013 Customer Satisfaction. Monitoring and Evaluation Guidelines (ISO 10004: 2012, IDT)» has been used as a methodological basis for sociological research.

The survey was conducted during the last three months of 2018.

A necessary condition for the patient to be a participant in the survey was observation by a dentist of the dental 
Table I. Socio-demographic respondents'specifications

\begin{tabular}{cccc}
\hline Registration Number & Description & \multicolumn{2}{c}{ Frequency } \\
\cline { 2 - 4 } & total & 221 & 100,0 \\
\hline 1 & including: & & \\
\hline 1.2 & male & 97 & 53.9 \\
\hline 1.3 & female & 124 & 56.1 \\
\hline 2 & urban residents & 118 & 53.4 \\
\hline 3 & villagers & 103 & 46.6 \\
\hline Registration Number & Description & Mean, \pm SD, years \\
\hline 4 & average age of all respondents & $45.8 \pm 12.6$ \\
\hline 5 & age male & $43.5 \pm 12.2$ \\
\hline
\end{tabular}

clinic for 1 year or more. A total of 229 people aged 18 and older took part in the survey; 221 copies of the questionnaires completed by the respondents was used. This was equal to $45.0 \%$ of patients from the average number of people who visited the dental clinic during the last quarter of 2013-2017. The patient selection was random.

The methodology of creating the questionnaire is founded on the generally accepted methodology and involved orientation towards the achievement of the established goals of sociological research; availability of instructions for the respondents to use the questionnaire; first location general questions and then location more specific questions; placement of difficult questions after more simple ones; a clear, specific, unambiguous wording of the questions.

The self-administered structured questionnaire was created according to basic characteristics of healthcare quality. The following quality characteristics were reviewed: geographical accessibility, clinical effectiveness (the result of dental care), financial accessibility, safety, patient-orientation. These target questions were used because is known their significant impact on patients' satisfaction.

According to these characteristics, respondents were asked to provide answers to the following questions:

1. How satisfied you are with the location of our clinic (how convenient it is for you to get from home to us).

2. How satisfied are you with the schedule of doctors (how convenient it is for you to visit a doctor on such a schedule).

3. How satisfied are you with the conditions in the doctor's office (cleanliness, lighting, air temperature, condition of the furniture, etc.).

4. How satisfied are you with the results of the treatment you received at the clinic.

5. How satisfied are you with the cost of paid services in our clinic (how much is this cost available to you).

6 . How satisfied are you with the safety of dental procedures in the clinic (how much do you consider yourself protected from the possibility of injury, infection, allergic reactions, moral damage).

7. How satisfied are you with the doctor's attitude towards you (how friendly was the attitude towards you).
8. How satisfied are you with the clarity of the information you received from your doctor about your dental problem.

9. How satisfied are you in overall with the quality of medical care in our clinic.

10. If your relatives / acquaintances need dental care, would you recommend them to contact our clinic?

A five-level digital measurement scale of responses was applied: points $1=$ Very poor, $2=$ Poor, $3=$ Fair, $4=$ Good, $5=$ Excellent.

The poll was conducted after obtaining informed consent of the patient to participate in the study, which is indicated in the introductory part of the questionnaire. The survey was conducted after the end of treatment.

Patient identification by surname, first name and date of birth was not carried out. This guaranteed the anonymity of the respondents.

The authors calculated descriptive statistical parameters: mean, \pm standard deviation (SD) and frequency $(\mathrm{N}, \%)$ by using the licensed Microsoft Office Excel 10 software.

Ethics commission Shupyk National Medical Academy of Postgraduate Education concluded the study complies with the current standards and principles of the "Code of Ethics of the Ukrainian Doctor", current regulations of Ukraine and the requirements of the Declaration of Helsinki (18.01.2021 protocol of Ethics commission No 1).

\section{RESULTS AND DISCUSSION}

Table I is presented socio-demographic respondents' specifications.

It is shown that the number of women - 124 (56.1\%) was more than the number of men $-97(43.9 \%)$ in the group of respondents. The average age of men was $43.5 \pm 12.2$ years, average age of women was $47.6 \pm 12.7$. These data indicated a higher rate of visits by women to the dentist and an earlier development of oral pathology in men. The group included 118 (53.4\%) urban residents and 103 $(46.6 \%)$ villagers due to the fact that the dental clinic of Chernigov, where the study was conducted, provides dental care to the population of the entire region. 
Table II. The date of patients' satisfaction with the received dental care

\begin{tabular}{ccc}
\hline $\begin{array}{c}\text { Questionnaire } \\
\text { number }\end{array}$ & Characteristics & Score in points, mean, \pm SD \\
\hline 1 & Geographical accessibility & $4.28 \pm 0.81$ \\
\hline 2 & Convenience of the schedule of reception of the doctor & $4.56 \pm 0.60$ \\
\hline 3 & Conditions in the doctor's office & $4.63 \pm 0.53$ \\
\hline 4 & Cesults of the treatment patient received at the clinic & $4.58 \pm 0.59$ \\
\hline 5 & Safety of dental procedures in the clinic & $3.76 \pm 0.80$ \\
\hline 6 & Doctor's attitude towards patient & $4,54 \pm 0,53$ \\
\hline 7 & Clarity of the information patient received from the doctor about dental problem & $4.75 \pm 0.49$ \\
\hline 8 & Overall patient's satisfaction with dental care in the clinic & $4.52 \pm 0.54$ \\
\hline 10 & Recommendations for acquaintances / relatives to use the services of this clinic & Some negative answers \\
\hline
\end{tabular}

Table II shows the mean points of patients' satisfaction with the received dental care.

The spread of the average values of satisfaction for these characteristics was in the range of 3.76-4.75. Overall patients' satisfaction with dental care in the clinic was $4.39 \pm$ 0.51 . This demonstrated a high level of patients' satisfaction, ranging from fair to good. This position was confirmed by the willingness of almost all patients to recommend the clinic to their friends and / or relatives in need of dental care. At the same time, patients were the least satisfied with the cost of dental services, since this quality characteristic was assessed as only $3.76 \pm 0.80$ points. This indicated the problem of financial accessibility of some respondents to dental services.

Assessments of patients' satisfaction with dental care in a regional clinic in Ukraine generally correspond to assessments obtained in similar studies in clinics in other countries and show high results. At the same time, the assessment of individual quality characteristics varies in comparison with the overall assessment.

The authors' data [5] show the high patients' satisfaction of the treatment process, doctor's attitude, organization and results of dental care, and its safety. However, the condition of the infrastructure components of the clinic received low marks.

According to research [6] low accessibility of dental care within the clinic reduced overall patients' satisfaction. The same studies have shown that the appearance of the clinic has an impact on patient satisfaction and can be used as a measure of satisfaction.

As a result of the research [7] proposed additional criteria for the quality of dental care: the attitude of non-medical personnel, the quality of patient reception, the organization of emergency dental care, and patient education on prevention of oral diseases.

Research [8] received confirmation of patients' satisfaction in the case of payment for dental services on preferential terms.

The relationship between the patient and the dentist, the qualifications of the doctor, the conditions of treatment and its accessibility shape the patient's perception of the quality of dental care [9].
According to the authors [10], patients are more satisfied with the medical care provided by female dentists and young doctors. Patients showed a high degree of satisfaction with the available dental care, adequate pain relief and an adequate amount of dental care.

The results of the study in Ukraine confirm the variety of criteria for the quality of dental care. In particular, financial accessibility is a very important component of patients' satisfaction. Health care reform is currently taking place in Ukraine. Only emergency dental care for the entire population and planned care for children is included in the package of state-guaranteed dental services for the population. Therefore, the results of the study can be used as information support for making managerial decisions on revising the financial coverage of dental services.

The research results are original, but representative only for the dental clinic in Chernigov. Therefore, it is necessary to continue sociological research in dental institutions in other regions of Ukraine. It is desirable to investigate the relationship of patient satisfaction with their socio-demographic characteristics.

\section{CONCLUSIONS}

The results of the study showed a high level of patients' satisfaction with dental care. However, survey data showed that satisfaction with financial inclusion was significantly lower than satisfaction with other quality components. This information can be used to make management decisions about providing financial coverage for dental services from the state budget and other funding sources.

\section{REFERENCES}

1. People-centred health services delivery: concept note. WHO Regional Office for Europe; 2014, 19 p.

2. DSTU ISO 10004:2013 (ISO 10004:2012, IDT) Natsionalnyi standart Ukrainy. Upravlinnia yakistiu. Zadovolenist zamovnykiv. Nastanovy shchodo monitorynhu ta otsiniuvannia [DSTU ISO 10004: 2013 (ISO 10004: 2012, IDT) National standard of Ukraine. Quality management. Customer satisfaction. Monitoring and evaluation guidelines]. Kyiv. Ministry of Economic Development of Ukraine; 2014, 29p. (in Ukrainian). 
3. DSTU EN 15224:2019 Systemy upravlinnia yakistiu. EN ISO 9001:2015 u sferi okhorony zdorovia (EN 15224:2016, IDT) [DSTU EN 15224: 2019 Quality management systems. EN ISO 9001: 2015 for healthcare (EN 15224: 2016, IDT)]. Kyiv, State Enterprise “UkrNDNTS"; 2020, 109 p. (in Ukrainian).

4. Zvit Holovnoi akredytatsiinoi komisii pry MOZ Ukrainy za 2017 rik [Report of the Main Accreditation Commission at the Ministry of Health of Ukraine for 2017]. URL: http://moz.gov.ua/uploads/1/5004zvit_gak_2017.pdf. (in Ukrainian).

5. Iqbal W., Faran F., Yashfika A.B. et al. Evaluation of Dental Care through Patient Satisfaction Feedback - A Cross Sectional Study at Dental Institute of OJHA Hospital, Karachi, Pakistan. Adv Dent \& Oral Health. 2018; 8(4): 555743. D0I: 10.19080/ADOH.2018.08.555743.

6. Ali D.A. Patient satisfaction in dental healthcare centers. Eur J Dent 2016;10:309-14. doi: 10.4103/1305-7456.184147.

7. Luo N.J.Yu., Liu P.P., Wong M.C. Patients' satisfaction with dental care: a qualitative study to develop a satisfaction instrument. BMCOral Health.2018; 18: 15. Published online 2018 Jan 30. doi: 10.1186/s12903-018-0477-7.

8. Bhat N., Sultane P., Chhabra S. et al. Assessment of Patient Satisfaction toward Dental Care Services of Patients visiting Dental Schools in Udaipur, Rajasthan, India. International Journal of Oral Care and Research. 2017; 5(1):34-41. doi: 10.5005/jp-journals-10051-0079.

9. Akbar F. H., Pasiga B. Patient Satisfaction Level with Health Care Quality at Dental Hospital of Hasanuddin University. Advances in Social Science, Education and Humanities Research (ASSEHR), volume 127.8th International Conference of Asian Association of Indigenous and Cultural Psychology (ICAAIP). 2017: 253-258.

10. Lin Y., Hong Y.A., Henson B.S. et al. Assessing Patient Experience and Healthcare Quality of Dental Care Using Patient Online Reviews in the United States: Mixed Methods Study. J Med Internet Res. 2020; 22(7):e18652.
This study was conducted within scientific and research (initiative-search) work of the Department of Public Health Management of Shupyk National Medical Academy of Postgraduate Education entitled "Reasoning of management models of health subsystems and strengthening of population health of Ukraine in accordance with European strategies" (2014-2019, № state registration 0115U002160).

\section{ORCID and contributionship:}

Anatoly G. Krut: 0000-0001-6503-3952 A, B, C

Viktoriia V. Horachuk: 0000-0002-6076-8711 D, E, F

\section{Conflict of interest:}

The Authors declare no conflict of interest.

\section{CORRESPONDING AUTHOR Anatoly G. Krut}

Shupyk national medical academy of postgraduate education 9 Dorohozhytska St., 04112 Kyiv, Ukraine

tel: +380442342029

e-mail akrut@ukr.net

Received: 20.11 .2020

Accepted: 09.03.2021

A - Work concept and design, B - Data collection and analysis, C - Responsibility for statistical analysis, D-Writing the article, $\mathbf{E}$ - Critical review, $\mathbf{F}$ - Final approval of the article 